\title{
Black Stork Back: Species distribution model predictions of potential habitats for Black Stork Ciconia nigra in Sweden
}

\author{
Svarta storkens återkomst: \\ Artutbredningsmodeller identifierar potentiella habitat \\ för svart stork Ciconia nigra i Sverige
}

\begin{abstract}
Carl-Gustaf Thulin"1, (iD, Malin Sörhammar ${ }^{2,3}$ (iD) \& Jonas Bohlin 4 iD
1 Department of Anatomy, Physiology and Biochemistry, Swedish University of Agricultural Sciences, 75007 Uppsala, Sweden | carl-gustaf.thulin@slu.se 22Department of Wildlife, Fish, and Environmental Studies, Swedish University of Agricultural Sciences, 90183 Umeå, Sweden ${ }^{3}$ Svenska Cellulosa Aktiebolaget (SCA), Skepparplatsen 1, 85188 Sundsvall, Sweden | malin.sorhammar@sca.com ${ }^{4}$ Department of Forest Resource Management, Swedish University of Agricultural Sciences, 90183 Umeå, Sweden | jonas.bohlin@slu.se

*Primary author for correspondence
\end{abstract}

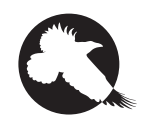

INCREASED UNDERSTANDING of the need to save endangered and locally extinct species has led to restoration or preservation of populations through reintroductions. Reintroduction of a species is worthwhile if the prerequisites for existence at the historical location have improved. Thus, background information about the habitat requirements of a target species is important for introduction programmes to be successful. The Black Stork Ciconia nigra was lost as a breeding species in Sweden during the $20^{\text {th }}$ century, but recent observations and reports of potential breeding indicate that habitat conditions for Black Stork in Sweden may have improved. In this study, we used species characteristics and references to identify habitats in Sweden suitable for potential reintroduction of Black Stork. We identified several suitable areas in the former distribution range of this species in southern Sweden. Seven Swedish counties contained more than $18 \%$ suitable habitat within their total area, with highest proportions in Jönköping County (25.8\%), Blekinge County (23.9\%), Västra Götaland County (22.1\%) and Kronoberg County (20.7\%). We suggest these areas to be made the primary targets for Black Stork reintroduction in Sweden. 


\section{Introduction}

The Black Stork Ciconia nigra is a typical forest bird, inhabiting old, sparse forests with limited disturbance frequency (Svensson et al. 1999, Banás et al. 2019) and a high density of watercourses and stagnant water (Augutis \& Sinkevičius 2005). Unlike the White Stork C. ciconia, which forages in open habitats, the Black Stork forages mostly in closed, isolated forests (Jiguet \& Villarubias 2004). The distance between the Black Stork nesting site and the foraging area can vary from six to 40 kilometres (Tucker \& Heath 1994, Chevallier et al. 2010a, Strazds 2011). Choice of the nesting tree depends on individual ability to build a nest, flyway accessibility to the tree and safety from avian and terrestrial predators, in particular White-tailed Eagle Haliaeetus albicilla and pine marten Martes martes (Strazds 2011). A Black Stork pair tends to return to the same nest tree if the breeding site is beneficial and the nest can ultimately weigh as much as 1,000 kilograms (Strazds 2003). Tree age is of less importance in the choice of nesting site (Lõhmus 2006), but a suitable nest tree must be relatively large in order to support the weight (Lõmus \& Sellis 2003, Treinys et al. 2008). The Black Stork prefers to nest in forests with a high proportion of broadleaved trees $(\sim 10-20 \%)$, or with a high proportion of aspen Populus tremula $(\sim 10-20 \%)$ if the proportion of other broadleaved trees is low (Treinys et al. 2009).

The global Black Stork population has dropped since the mid-180os, especially in central and western parts of Europe, most likely due to intensified forestry and habitat degradation (Tucker \& Heath 1994). However, this trend has since been reversed in many western European countries and the population is currently considered to be stable in a large proportion of the distribution range (Jiguet et al. 2011). Recent recolonisations have been documented in Denmark and Belgium (Pihl et al. 2003, Tamás 2011). Regionally, however, the trend is still negative. A dramatic population decline persists in Estonia, Latvia and Lithuania (Treinys et al. 2008). In Sweden, the oldest remnants of Black Stork are found at an excavation near Ystad in southernmost Sweden, thought to stem from a nesting female 5,000 years before present (Davner 1993). During the mid-19 ${ }^{\text {th }}$ century, the species was found from southern to central Sweden (Svensson et al. 1999, Lindell 2002). However, the distribution and number of Black Storks then began to decline rapidly and in the $20^{\text {th }}$ century the species was lost as a regular breeding bird in Sweden (Ulfstrand 1973).

Loss of habitats and lack of suitable nesting sites adjacent to wetlands and small streams are likely reasons for Black Stork disappearance in Sweden (Artfakta 2020a). Additional reasons may be the use of pesticides (Luthin 1987, Jiguet \& Villarubias 2004) and possible threats during the migration, such as illegal hunting and powerline and wind turbine accidents (Tucker \& Heath 1994, Smeraldo et al. 2020). Black Storks have been observed sporadically in Sweden since the last documented nesting in 1953 (Svensson et al. 1999). In the 1990 s, ornithologists and scientists suggested that it was only a matter of time before Black Stork established again in Sweden (Davner 1993), but establishment has so far failed to appear, even though Black Storks are observed annually.

A reintroduction programme requires a detailed analysis of the ecology and environmental requirements of the target species, i.e., its social behaviour, size of home range and foraging behaviour (Armstrong \& Seddon 2008), but also of habitat availability at intended reintroduction sites. Species distribution models based on biological characteristics of a species and previously described habitat preferences have been used to describe the geographical distribution of species and can be a promising tool to guide the planning of species reintroductions by conservation biologists (Meggs et al. 2004, Powell et al. 2005, Poirazidis et al. 2006, Lord et al. 2020). The expected geographical distribution of a species can be predicted by defining a number of features such as vegetation, soil, or climate, which determine the environmental preferences (Powell et al. 2005). The increasing availability of digitised maps and tools in different geographic information systems (GIS) has helped to improve territory analysis and characterisation of habitats (Thatcher et al. 2006). The creation of habitat models has contributed to the development of conservation biology for species in danger of extinction at several spatial levels (Powell et al. 2005). Wintle et al. (2005) claim that, if a habitat model is applied properly, it could be a good and repeatable technique to use in identification of biodiversity values.

In order to facilitate a future reintroduction program for Black Stork in Sweden, we used species distribution models to identify areas suitable for Black Stork breed- 
ing in southern and central Sweden, and integrated the model results with practical considerations of reintroduction of Black Stork.

\section{Material and methods}

\section{HABITAT ATTRIBUTES}

The estimated habitat area for a breeding Black Stork pair is reported to range from 5,000 to 15,000 hectares (Tucker \& Heath 1994, Jiguet \& Villarubias 2004, Artfakta 2020a). However, in a study in Lithuania the area of 2,500 hectares surrounding each of 81 nests was described in detail, revealing that on average the habitat comprised at least $13 \%$ forest cover, at least $10 \mathrm{~km}$ of watercourses longer than $10 \mathrm{~km}$, and less than $5.5 \%$ disturbance objects (Treinys et al. 2008). Thus, in this study, we used the detailed criteria identified by Treinys et al. (2008) and a habitat area of 2,500 hectares around each nest as minimum environmental requirements (Table 1). Watercourses in the analysis were defined as running water including everything from a small brook to a large river (SVAR 2011). Smaller water bodies of stagnant water, such as flooded ditches, were not included in the analysis, due to lack of data. Furthermore, at least 125 hectares (5\%) within 2,500 hectares of suitable habitat for Black Stork had to meet the requirements for suitable nesting sites (Treinys et al. 2009).

In order to model suitable nesting sites, all variables had to be met within an area of one hectare (Table 2). The standard error has a tendency to decrease with the number of aggregated cells and thus the accuracy of estimation may be improved (Næsset 2002). Data on the maximum proportion of Norway spruce Picea abies and the minimum proportions of broadleaved trees, aspen and Scots pine Pinus sylvestris were obtained from Treinys et al. (2009), see Table 2. According to Strazds (2011), the minimum diameter of a nesting tree is 28.0 centimetres and the average tree diameter in a stand of nesting Black Storks is 29.3 centimetres. Therefore, we decided to use 29 centimetres as the lower limit for tree diameter in the GIS analysis (Table 2). A distance of 280 metres between a potential nesting site for Black Stork and infrastructure elements is recommended by Treinys et al. (2009). The value used in this study was rounded to 300 metres, to give a larger margin to disturbance objects. The geographical area used in the analysis was limited to the historically known distribution range of Black Stork in the southern part of Sweden, with Dalarna and Gävleborg Counties as northern borders (Figure 1).

\section{MATERIAL}

The input data to the models and their spatial resolution are described in Table 3 . Stem volume of the different tree species was extracted from the "kNN-Sweden" forest map (Granqvist Pahlén et al. 2004), which is derived from satellite images and field data from the Swedish National Forest Inventory and " $k$ Nearest Neighbour" as described by Franco-Lopez et al. (2001). The information in the $\mathrm{kNN}-\mathrm{Sw}$ eden map is uncertain if the areas analysed are too small. The standard error of the total stem volume of tree species is $10-15 \%$ for estimates of areas of 100 hectares (Granqvist Pahlén et al. $2004)$. The basal area weighted mean diameter $\left(D_{B W}\right)$ of the different tree species was extracted from the Swedish forest attribute map (Nilsson et al. 2017). Roads and railways were selected from the National Road map, which contains a detailed and comprehensive description of Swedish 
TABLE 2. Variables used in geographic information systems (GIS) analysis of potential nesting trees for Black Stork Ciconia nigra. - Variabler som användes vid GIS-analysen av möjliga boträd för svart stork Ciconia nigra.

\begin{tabular}{|c|c|c|c|}
\hline $\begin{array}{l}\text { Life prerequisite } \\
\text { Livsvillkor }\end{array}$ & $\begin{array}{l}\text { Variable } \\
\text { Variabel }\end{array}$ & $\begin{array}{l}\text { Value } \\
\text { Värde }\end{array}$ & $\begin{array}{l}\text { Area } \\
\text { Area }\end{array}$ \\
\hline $\begin{array}{l}\text { Nesting } \\
\text { Bobygge }\end{array}$ & $\begin{array}{l}\text { Presence of large potential nest trees, basal area weighted mean diameter }\left(D_{B W}\right) \\
\text { Förekomst av stora potentiella boträd, viktad medeldiameter av basalarean }\left(D_{B W}\right)\end{array}$ & $\geq 29 \mathrm{~cm}$ & 1 hectare \\
\hline $\begin{array}{l}\text { Nesting } \\
\text { Bobygge }\end{array}$ & $\begin{array}{l}\text { Presence of Norway spruce Picea abies } \\
\text { Förekomst av gran Picea abies }\end{array}$ & $\leq 10 \%$ & 1 hectare \\
\hline $\begin{array}{l}\text { Nesting } \\
\text { Bobygge }\end{array}$ & $\begin{array}{l}\text { Presence of European oak Quercus robur, European beech Fagus sylvatica, } \\
\text { other deciduous tree species, or Scots pine Pinus sylvestris } \\
\text { Förekomst av ek Quercus robur, bok Fagus sylvatica, andra lövträd eller tall } \\
\text { Pinus sylvestris }\end{array}$ & $\geq 30 \%$ & 1 hectare \\
\hline $\begin{array}{l}\text { Safety } \\
\text { Säkerhet }\end{array}$ & $\begin{array}{l}\text { Distance to infrastructure elements } \\
\text { Avstånd till infrastruktur }\end{array}$ & $\geq 300 \mathrm{~m}$ & 1 hectare \\
\hline
\end{tabular}

transport infrastructure. Forest data and information on watercourses and disturbance objects were extracted from the Swedish Land Cover Data (SMD; Swedish Environmental Protection Agency 2014), a refined national version based on the EU classification system CORINE Land Cover (INSPIRE Thematic Working Group Land Cover 2013). According to SMD, forests are defined as areas with trees of at least 5 metres in height and with canopy cover of more than $30 \%$ (Ahlcrona 2003). The counties used in the GIS analysis were selected from the county map of Sweden and extracted to a new polygon layer. All input data were converted to the size of this polygon layer of counties.

\section{METHOD}

Habitat modelling was carried out in ArcGis 10 (Environmental Systems Research Institute, Redlands, California, USA), using a moving window approach

TABLE 3. Input data used for Black Stork Ciconia nigra habitat modelling.

- Indata för habitatmodellen för svart stork Ciconia nigra.

\begin{tabular}{lc}
\hline $\begin{array}{l}\text { Dataset } \\
\text { Dataset }\end{array}$ & $\begin{array}{l}\text { Raster cell size (m) or scale } \\
\text { Rastercellstorlek }(m) \text { eller skala }\end{array}$ \\
\hline $\begin{array}{l}\text { kNN-Sweden forest map } \\
\text { Skogskartan kNN-Sverige }\end{array}$ & 25 \\
$\begin{array}{l}\text { Swedish forest attribute map } \\
\text { Svenska skogsegenskapskartan }\end{array}$ & 12.5 \\
$\begin{array}{l}\text { National road map } \\
\text { Nationella GSD-Vägkartan }\end{array}$ & $1: 100,000$ \\
$\begin{array}{l}\text { Swedish land cover data } \\
\text { Svenska Marktäckedata (SMD) }\end{array}$ & 25 \\
\hline
\end{tabular}

with a window size of one hectare. A raster cell was considered a nesting site if, on average, the $\mathrm{D}_{\mathrm{BW}}$ value was larger than $29 \mathrm{~cm}$, the proportion of Norway spruce was less than $10 \%$, the combined proportion of European beech Fagus sylvatica, European oak Quercus robur, Scots pine or other deciduous species was at least $30 \%$ and the Euclidian distance to infrastructure elements was more than 300 metres.

For modelling the full habitat requirements, i.e., both foraging and nesting, a similar moving window approach was used. A raster cell was considered a possible habitat if, within a 2,500-hectare window, less than $5.5 \%$ of the area was disturbance objects, there was more than $10 \mathrm{~km}$ of total waterways, more than $13 \%$ of the area was forest cover, and at least $5 \%$ of the area was suitable nesting areas. Finally, the sum and the proportion of suitable habitat cells were calculated for each county.

\section{Results and discussion}

The overall modelling process involved several steps, such as conversion of data, calculations, and merging of the data layers. Based on the selected variables, suitable habitats were found in every county included in the analysis except Gotland (Table 4). Seven counties contained more than $18 \%$ suitable habitat within their total area, while the remaining counties contained less than $10 \%$ suitable habitat (Table 4 ). The highest proportion of suitable habitat in relation to total area was found in Jönköping County ( $25.8 \%)$, followed by Blekinge (23.9\%), Västra Götaland (22.1\%), and Kronoberg 


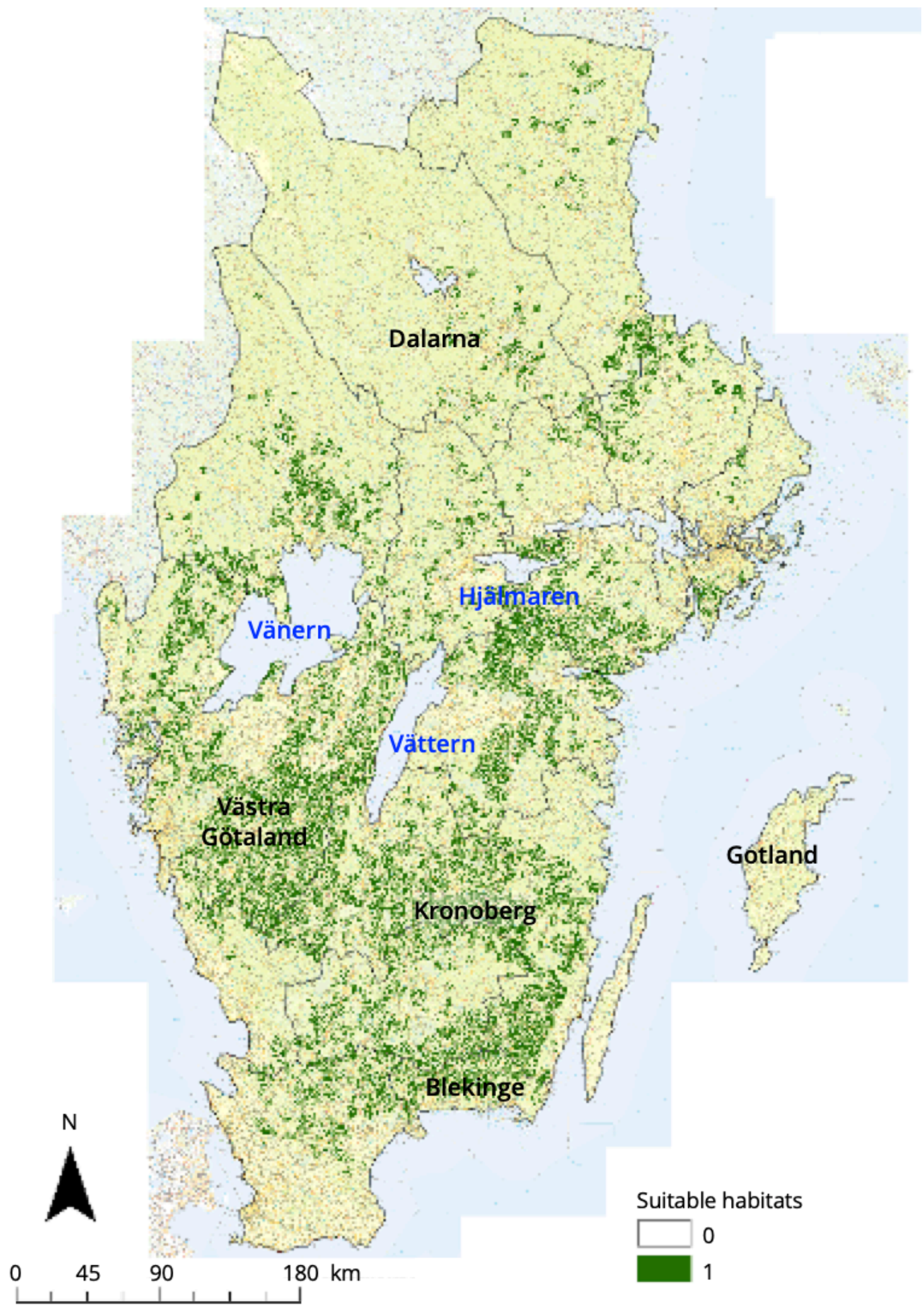


FIGURE 1 (previous page). Distribution of suitable habitats (dark green) for Black Stork Ciconia nigra, according to species distribution modelling following predefined criteria (Table 1), within the 17 counties of southern and central Sweden. The highest proportion of suitable habitats in relation to total area was found in Jönköping County (25.8\%), followed by Blekinge (23.9\%), Västra Götaland (22.1\%), and Kronoberg (20.7\%) Counties, while the lowest proportion (1.8\%) was found in Dalarna County. No suitable habitat (0\%) was defined on the Baltic Sea island of Gotland. Lakes Vänern, Vättern and Hjälmaren are depicted in blue. @Lantmäteriet, i2014/764. - Utbredning av lämpliga habitat (mörkgrönt) för svart stork Ciconia nigra, utifrån artutbredningsmodellering som följer på förhand definiterade kriterier (tabell 1), i 17 län i södra och mellersta Sverige. Största andelen lämpliga habitat i förhållande till total yta fanns $i$ Jönköpings län (25,8\%), följt av Blekinge län (23,9\%), Västra Götalands län (22,1\%) och Kronobergs län (20,7\%), medan den lägsta andelen (1,8\%) fanns i Dalarnas län. Lämpliga habitat saknades helt (0\%) på Gotland. Sjöarna Vänern, Vättern och Hjälmaren är märkta med blå text. CLantmäteriet, i2014/764.

(20.7\%) Counties, while the lowest proportion (1.8\%) was in Dalarna County. No habitat (o\%) was identified on the island of Gotland (Gotland County) in the Baltic Sea (Figure 1). Altogether, the 17 counties included in the analysis contained $21,705 \mathrm{~km}^{2}$ of suitable Black Stork habitats (Table 4).

\section{GIS ANALYSIS}

The results of the GIS analysis indicated extensive availability of suitable breeding habitats for reintroduction of Black Stork in Sweden. In particular, suitable areas for reintroduction were identified in the vicinity of the lakes Vänern, Vättern, and Hjälmaren, and towards the southeast in the counties of Blekinge and Kronoberg (see Figure 1). This is a reasonable finding because of the proximity to water and watersheds and the presence of a large number of restored wetlands, ponds, and dams in these areas. They also provide a mixture of arable land and forests, particularly forest with a relatively larger proportion of deciduous trees. The absence of suitable habitat patches on Gotland and in northern Dalarna seems plausible, since large parts of Dalarna are composed of near-alpine forests and have a harsh climate, unsuitable for the Black Stork. The former distribution limit of the species was near the Dalälven river (Lindell 2002). There has been speculation about whether the Baltic Sea acts as a barrier for Black Stork migration (Davner 1993), meaning that Gotland with its relatively remote location from the mainland may not be appropriate as a nesting site. However, observations of Black Stork have been made on Gotland, which indicates that Black Stork is not prevented from migrating over longer distances of open water, as suggested by Davner (1993). Nevertheless, many watercourses on Gotland have been affected by human activities such as dredging, which results in unnaturally rapid outflow during winter and dried-up watercourses during summer (Gullefors \& Johanson 2007). The requirement of at least 10 kilometres of contiguous watercourses may be a reason why we did not find suitable habitats on Gotland, where watersheds are scarce. In addition to Gotland, Black Storks have also been observed in Västra Götaland and Östergötland (Artfakta 2020a). However, compared with Gotland, there were plenty of suitable habitats in both Västra Götaland and Östergötland. In our opinion, this range of findings strengthens the applicability of the results and the reliability of the variables and analyses used. Concerns would have arisen if areas everywhere had been identified as suitable habitats.

The current estimated density of breeding Black Stork pairs varies from 1.34 per $100 \mathrm{~km}^{2}$ in Eastern Austria (Sackl 1985) to 10.8 per $100 \mathrm{~km}^{2}$ in the Dadia-Lefkimi-Soufli Forest National Park in north-eastern Greece (Alexandrou et al. 2016). Thus, although it is not certain that there is an absolute need for contiguous habitat of at least 2,500 hectares for breeding Black Storks, as postulated in our models, it seems reasonable based on Sackl 1985 and Alexandrou et al. 2016 (i.e., $0.33-2.7$ breeding pairs / 2,500 hectares). The size of the habitat likely varies depending on the quality, assuming that the higher the quality, the smaller the area required. We suggest that habitat patches of 2,500 hectares are suitable if they are sufficiently undisturbed and contain enough large trees for nesting, since a number of studies indicate that Black Storks can fly several kilometres to forage and thus remoteness is not necessarily a limiting factor (cf. Strazds 2011).

\section{REINTRODUCTION SUITABILITY}

A core issue for a successful reintroduction programme is presence of key prerequisites in the intended reintroduction area, which requires extensive knowledge of the biology of the species in question. The reason behind the recent population declines in Estonia, Latvia and Lithuania (Treinys et al. 2008) is unclear (Zieliński 2006), but it could be due to intensified forestry and habitat degradation (Tucker \& Heath 1994), predator 
TABLE 4. Area and proportion of suitable habitat for Black Stork Ciconia nigra in each of the 17 counties in southern and central Sweden included in the present analysis.

- De län som inkluderades i analysen samt ytan och andelen lämpliga habitat för svart stork Ciconia nigra $i$ vart och ett.

\begin{tabular}{|c|c|c|}
\hline $\begin{array}{l}\text { County } \\
\text { Län }\end{array}$ & $\begin{array}{l}\text { Area of suitable habitat }\left(\mathrm{km}^{2}\right) \\
\text { Andel lämpligt habitat }\left(\mathrm{km}^{2}\right)\end{array}$ & $\begin{array}{l}\text { Proportion (\%) suitable habitat } \\
\text { Andel (\%) lämpligt habitat }\end{array}$ \\
\hline Stockholm & 210.2 & 3.2 \\
\hline Uppsala & 675.8 & 8.3 \\
\hline Södermanland & $1,120.4$ & 18.5 \\
\hline Östergötland & $2,068.1$ & 19.6 \\
\hline Jönköping & $2,706.3$ & 25.8 \\
\hline Kronoberg & $1,747.9$ & 20.7 \\
\hline Kalmar & $2,116.0$ & 18.9 \\
\hline Gotland & 0.0 & 0.0 \\
\hline Blekinge & 703.7 & 23.9 \\
\hline Skåne & $1,001.0$ & 9.1 \\
\hline Halland & 485.6 & 8.9 \\
\hline Västra Götaland & $5,283.7$ & 22.1 \\
\hline Värmland & $1,483.9$ & 8.4 \\
\hline Örebro & 690.1 & 8.1 \\
\hline Västmanland & 308.2 & 6.0 \\
\hline Dalarna & 500.1 & 1.8 \\
\hline Gävleborg & 603.9 & 3.3 \\
\hline $\begin{array}{l}\text { Summay } \\
\text { Sammantaget }\end{array}$ & $21,704.9$ & \\
\hline
\end{tabular}

current population increase seen in Western Europe could be the result of a migrating population of Black Storks from Eastern Europe searching for new nesting sites (Chevallier et al. 2010c). On the other hand, Treinys et al. (2008) argue that an ongoing ecological change is occurring in the western and central European populations, allowing Black Storks to establish in fragmented forest areas in agricultural landscapes.

As suggested by our GIS modelling, there are several areas in southern Sweden that may be suitable for Black Stork reintroduction. There are also indications that the Black Stork is favoured by the presence of the European beaver Castor fiber (Tucker \& Heath 1994, Svensson et al. 1999). Through the construction of dams and lodges, the beaver frequently causes accumulation of new water bodies, which the stork can avoidance (e.g. Treinys et al. 2016) and shortage of potential mates in margin populations (Konovalov et al. 2019). Rosenvald \& Lõhmus (2003) point out that forestry activities are not the only factor causing population decline, but are likely to be strongly linked to a decline. Forest logging escalated in the Baltic countries after 1991 (Kurlavicius et al. 2004). This resulted in destruction of nesting habitats and contributed to impaired breeding opportunities (Lõhmus et al. 2005). More than $50 \%$ of the European population is currently distributed in Eastern Europe (Chevallier et al. 2010b), with the highest population density in the Balkan countries, northern Ukraine, Germany, north-eastern Poland, and western Russia (Lõhmus et al. 2005). The utilise in its scavenging for food (Svensson et al. 1999). In Latvia, a positive correlation between the two species has been found, with a high density of Black Stork in areas where the beaver is most frequent (Strazds 2011). The beaver, once extinct in Sweden, was reintroduced in 1922 and the population now exceeds 100,000 individuals, with an increasing trend (Hartman 1994, Hartman 2011). Beaver observations have been reported for many areas in southern and central Sweden (Figure 2). The potential interdependence of beaver and Black Stork (e.g. Tucker \& Heath 1994, Svensson et al. 1999), and the current distribution of beaver in Sweden, suggest that it may be favourable to release Black Storks in areas where the two species can coexist, in particular 
where beaver observations coincide with suitable Black Stork habitats revealed from our study.

Public attitudes can determine whether a conservation effort succeeds or fails (Bremner \& Park 2007), particularly if the effort is perceived by the public as controversial, as species reintroductions may be (Jacobson \& Duff 1998). However, public acceptance of captive breeding with subsequent reintroductions has increased and, consequently, the number of reintroduction projects has also increased (Seddon et al. 2007). An example is the reintroduction of the White Stork in Sweden (www.storkprojektet.se), for which the public attitude to capture and release of individuals is almost exclusively positive (Emma Ådahl, pers. comm. 2021). A similar positive attitude could be expected to reintroduction of the Black Stork, as the two species disappeared from Sweden at about the same time (Olsson \& Rogers 2009, Svensson et al. 1999).

Reintroduction can be implemented using captivity-bred or wild-caught animals (Meltofte 1987, Sarrazin \& Barbault 1996). The potential for successful reintroduction is lower when the animals are bred in captivity compared with when they are caught in the wild and transported to new habitats (Griffith et al. 1989). However, the conditions for successful reintroduction of captive-bred animals improve if the animals are well managed, have sufficient amount of genetic variation a broad genetic material, and are prepared for life in the wild through self-contained behaviour in the enclosures (Kleiman 1989). For successful reintroduction in Sweden, several pairs of Black Storks are needed to reduce the risk of inbreeding and increase the gene pool (Jamieson 2011). In the case of a species which is experiencing a decrease in numbers in several countries, it may be sensible to use specimens from breeding facilities and avoid wild-caught birds. There may also be a risk of wild-caught birds returning to their original location (Oppel \& Beaven 2002).

At a White Stork breeding facility, the birds must be ringed and provided with food of good quality, and the enclosures must be cleaned and in good condition. Facility employees must be trained to use techniques to prepare the animals for life in the wild, where they must be able to search for food, avoid predators, and construct nests (Kleiman 1989). The environment in enclosures can be limited and the animals may develop stress and behavioural problems over longer (Young
2003) or shorter periods (Coddington \& Cree 1995). Employees in the Swedish White Stork project have not noticed any behavioural change in the birds that has resulted in reduced vitality in the wild (E. Ådahl, pers. comm.). However, the behaviour of the Black Stork is different from that of the White Stork. For instance, when there are numerous adult Black Storks in captivity, they can behave belligerently towards each other

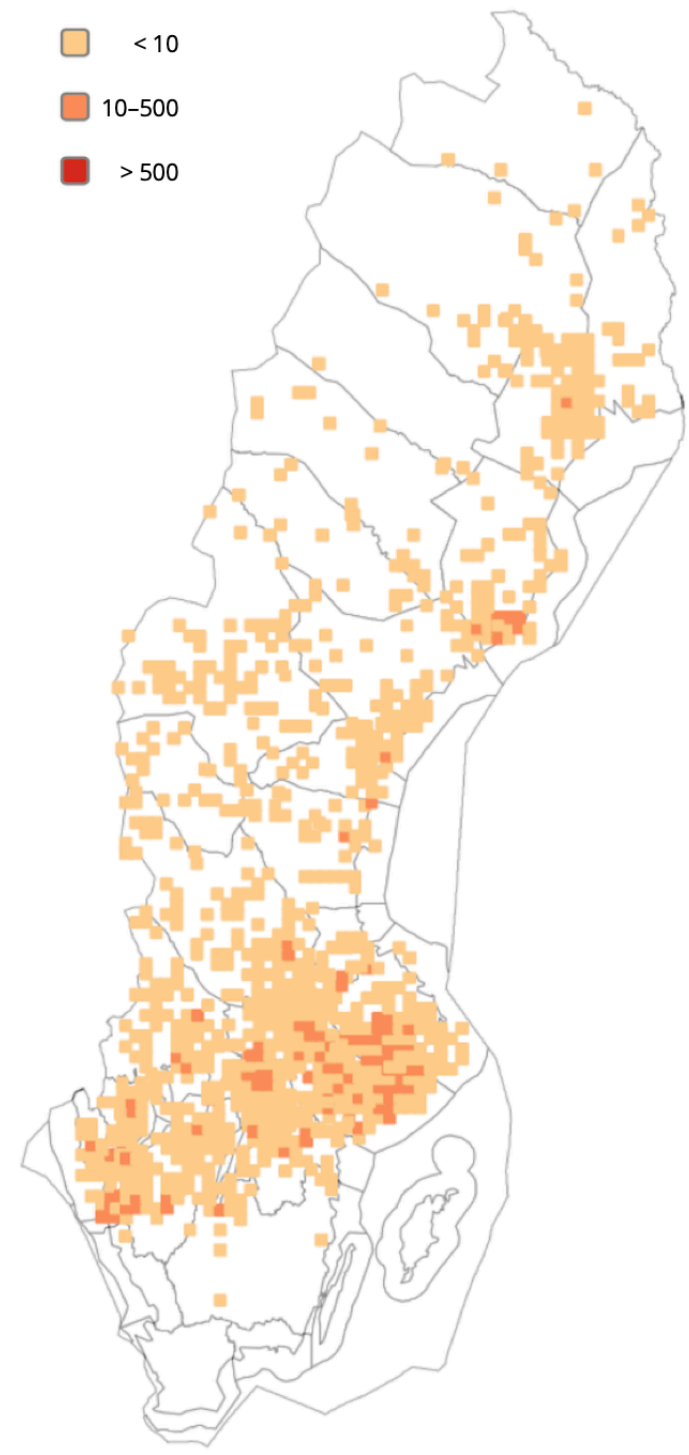

FIGURE 2. Locations of recent European beaver Castor fiber observations in Sweden (Artfakta 2020b).

- Observationer av bäver Castor fiber i Sverige (Artfakta 2020b). 
(Bračko \& King 2014). Two Black Stork pairs cannot live in the same enclosure at the same time without a risk of harming each other (Staffan Åkeby, pers. comm.). Thus, a system with geographically separated breeding facilities needs to be developed for Black Storks.

The climate has an effect on the survival of species and certain weather conditions or temperatures may pose obstacles for a species (Olsson 2007). The mortality rate in Black Stork chicks increases with bad weather conditions (Treinys et al. 2007), which has been suggested as an underlying cause of Black Stork disappearance in Sweden. However, over time the weather in Sweden has constantly fluctuated from warmer to colder and from drier to wetter, and vice versa, and Black Storks have been breeding in Sweden since at least 3,000 BC (Davner 1993). Moreover, the Black Stork does not seem very sensitive to climate conditions over its wide distribution from Western Europe to East Asia (Hancock et al. 1992). However, the Black Stork is sensitive to habitat requirements, especially for the choice of nesting site. If a reintroduction programme is launched, Swedish forest management must take into account the habitat requirements of Black Stork during logging and leave groups of thick, old trees of mainly European oak, European beech, aspen and Scots pine. It is also important to avoid drainage of forests, to provide wetlands for Black Stork to forage in, and potentially to regulate beaver hunting to facilitate wetland establishment. Old forests with high humidity may also be of significance for other endangered species (Berg et al. 1995) and thus restoration efforts that aim to create suitable habitats for Black Stork may also benefit other forest-dwelling species.

An additional challenge for Black Stork reintroduction is the migratory behaviour, as the European population of this species spends roughly half the year in its wintering grounds in west or east Africa, heading northwards in April for the breeding season and returning to Africa at the end of August (Lindell 2002), bypassing the eastern or western parts of Europe (Bobek et al. 2008). This may be a delicate matter to overcome, but experiences from the Swedish White Stork project and other reintroduction programmes with migratory species show that this challenge is not insurmountable. The Baltic Sea may serve as a migration barrier that has added to the disappearance of Black Stork from Sweden (Davner 1993). However, the Black Stork tends to migrate longer distances over open water than the White Stork (Bauer \& Glutz von Blotzheim 1966, see Hancock et al. 1992, p. 71). Thus, a reintroduction programme in Sweden could be reinforced with spontaneous immigration of Black Storks from overseas that intermix with released birds.

\section{Conclusions}

We believe that it is worthwhile to launch an effort to restore a breeding Black Stork population in Sweden. Using species distribution modelling, we showed that the necessary habitat requirements are fulfilled in part of southern and central Sweden. A warmer climate, along with the ongoing spread of beavers that spontaneously create wetlands in forested areas, would further facilitate restoration efforts. We also believe that there would be a positive public engagement in Black Stork reintroduction, since this is a charismatic species with a specific mystique that does not impinge on other interests in areal land use. Challenges in reintroduction work include the establishment of breeding infrastructure, finding stock animals, enabling released birds to migrate and, of course, acquiring funding for the work. However, these challenges should not hinder efforts to re-establish the Black Stork in Sweden.

\section{Acknowledgements}

Thanks to Maris Strazds for valuable advice, to Mary McAfee for improving the English, to Artur Larsson for assistance with Figure 2, and to two anonymous reviewers for suggestions that improved the manuscript.

\section{References}

Artfakta. 2020a. Svart stork Ciconia nigra. ArtDatabanken, SLU. https://artfakta.se/artbestamning/taxon/ciconia-nigra-100032 [2020-08-12]

Artfakta. 202ob. Bäver Castor fiber. ArtDatabanken, SLU. https://artfakta.se/artbestamning/taxon/castor-fiber-102607 [2020-08-12]

Ahlcrona E. 2003. Nomenklatur och klassdefinitioner. SCMD-ooo1, appendix 1. Lantmäteriet - Svenska CORINE Marktäckedata 2003:2.3.

Alexandrou O, Bakaloudis DE, Papakosta MA \& Vlachos CG. 2016. Breeding density, spacing of nest-sites and breeding performance of black storks Ciconia nigra in Dadia-Lefkimi-Soufli Forest National Park, north-eastern Greece. North-Western Journal of Zoology 12: 7-13.

Angelstam P, Roberge JM, Lõhmus A, Bergmanis M, Brazaitis G, 
Dönz-Breuss M, Edenius L, Kosinski Z, Kurlavicius P, Lārmanis V, Lūkins M, Mikusiński, G, Račinskis E, Strazds M \& Tryjanowski P. 2004. Habitat modelling as a tool for landscape-scale conservation: a review of parameters for focal forest birds. Ecological Bulletins 51: 427-453. https://www.jstor.org/stable/20113327

Armstrong DP \& Seddon PJ. 2008. Directions in reintroduction biology. Trends in Ecology and Evolution 23: 20-25. https://doi. org/10.1016/j.tree.2007.10.003

Augutis D \& Sinkevičius S. 2005. Application of Geographic Information System (GIS) technologies in identification of potential nesting habitats of black stork (Ciconia nigra). Acta Zoologica Lituanica 15: 3-12. https://doi.org/10.1080/13921657.2005.10512603

Banás J, Zieba S, Bujoczek M \& Bujoczek L. 2019. The impact of different management scenarios on the availability of potential forest habitats for wildlife on a landscape level: The case of the Black Stork Ciconia nigra (Linnaeus, 1758). Forests 10: 362 . https:// doi.org/10.3390/f10050362

Berg Å, Ehnström B, Gustafsson L, Hallingbäck T, Jonsell M \& Weslien J. 1995. Threat levels and threats to red-listed species in Swedish forests. Conservation biology 9: 1629-1633. https://www. jstor.org/stable/2387206

Björse G \& Bradshaw R. 1998. 2000 years of forest dynamics in southern Sweden: suggestions for forest management. Forest Ecology and Management 104: 15-26. https://doi.org/10.1016/ So378-1127(97)00162-X

BirdLife International. 2017. Ciconia nigra (amended version of 2016 assessment). The IUCN Red List of Threatened Species 2017: e.T22697669A111747857. https://doi.org/10.2305/IUCN.UK.20171.RLTS.T22697669A111747857.en [2020-08-12]

Bobek M, Hampl R, Peške L, Pojer F, Šimek J \& Bureš S. 2008. African Odyssey project-satellite tracking of black storks Ciconia nigra breeding at a migratory divide. Journal of Avian Biology 39: 500-506. https://doi.org/10.1111/j.0908-8857.2008.04285.x

Bračko A \& King CE. 2014. Advantages of aviaries and the Aviary Database Project: a new approach to an old housing option for birds. International Zoo Yearbook 48: 166-183. https://doi. org/10.1111/izy.12035

Bremner A \& Park K. 2007. Public attitudes to the management of invasive non-native species in Scotland. Biological Conservation 139: 306-314. https://doi.org/10.1016/j.biocon.2007.07.005

Chevallier D, Le Maho Y, Brossault P, Baillon F \& Massemin S. 2010a. The use of stopover sites by Black Storks (Ciconia nigra) migrating between West Europe and West Africa as revealed by satellite telemetry. Journal of Ornithology 152: 1-13. https://doi.org/10.1007/ S10336-010-0536-6

Chevallier D, Le Maho Y, Baillon F, Duponnois R, Dieulin C, Brossault P, De Franclieu P, Lorge P, Aurouet A \& Massemin S. 2010b. Human activity and the drying up of rivers determine abundance and spatial distribution of Black Storks Ciconia nigra on their wintering grounds. Bird Study 57: 369-38o. https://doi. org/10.1080/00063651003678467

Chevallier D, Duponnois R, Baillon F, Brossault P, Grégoire JM, Eva H, Le Maho Y \& Massemin S. 2010c. The importance of roosts for Black Storks Ciconia nigra wintering in West Africa. Ardea 98: 91-96. https://doi.org/10.5253/078.098.0111

Coddington EJ \& Cree A. 1995. Effect of acute captivity stress on plasma concentrations of corticosterone and sex steroids in female whistling frogs Litoria ewingi. General and Comparative Endocrinology 100: 33-38. https://doi.org/10.1006/gcen.1995.1129

Davner L. 1993. Locka svart stork med mera vatten. Skogen 8: 47. Granqvist Pahlén T, Nilsson M, Egberth M, Hagner O \& Olsson H. 2004. kNN-Sverige: Aktuella kartdata över skogsmarken. Fakta skog 12. https://www.slu.se/globalassets/ew/ew-centrala/forskn/ popvet-dok/faktaskog/faktaskogo4/fso4-12.pdf

Griffith B, Scott JM, Carpenter JW \& Reed C. 1989. Translocation as a species conservation tool: status and strategy. Science 245: 477-480. https://doi.org/10.1126/science.245.4917.477

Gullefors B \& Johanson KA. 2007. Gotlands nattsländor (Trichoptera). Entomologisk Tidskrift 128: 61-70. http://www.sef.nu/ download/entomologisk_tidskrift/et_2007/ET2007\%2061-70.pdf

Hancock J, Kushlan JA, Kahl MP, Harris A \& Quinn D. 1992. Storks, ibises and spoonbills of the world. Academic Press, London, UK.

Hartman G. 1994. Long-Term Population Development of a Reintroduced Beaver (Castor fiber) Population in Sweden. Conservation Biology 8: 713-717. https://doi.org/10.1046/j.1523-1739.1994.08030713.x

Hartman G. 2011. The beaver (Castor fiber) in Sweden. Pp 13-17 in Restoring the European Beaver: 50 years of Experience (Sjöberg G \& Ball JP, eds). Pensoft Publishers, Sofia, Bulgaria \& Moscow, Russia.

INSPIRE Thematic Working Group Land Cover 2013. D2.8.II.2 INSPIRE Data Specification on Land Cover - Technical Guidelines. European Commission Joint Research Centre, Ispra, Italy. https:// inspire.ec.europa.eu/id/document/tg/lc

Jacobson SK \& Duff MD. 1998. Training idiot savants: the lack of human dimensions in conservation biology. Conservation Biology 12: 263-267. https://doi.org/10.1111/j.1523-1739.1998.97235.x

Jamieson IG. 2011. Founder effects, inbreeding, and loss of genetic diversity in four avian reintroduction programs. Conservation Biology 25: 115-123. https://doi.org/10.1111/j.1523-1739.2010.01574.x

Jiguet F \& Villarubias S. 2004. Satellite tracking of breeding black storks Ciconia nigra: new incomes for spatial conservation issues. Biological Conservation 120: 153-16o. https://doi.org/10.1016/j. biocon.2004.02.007

Jiguet F, Barbet-Massin M \& Chevallier D. 2011. Predictive distribution models applied to satellite tracks: modelling the western African winter range of European migrant Black Storks Ciconia nigra. Journal of Ornithology 152: 111-118. https://doi.org/10.1007/ s10336-010-0555-3

Kleiman DG. 1989. Reintroduction of captive mammals for conservation: Guidelines for reintroducing endangered species into the wild. BioScience 39: 152-161. http://www.jstor.com/stable/1311025

Konovalov A, Nellis R, Nellis R, Nurmla A, Sellis U \& Väli Ü. 2019. Solitude at periphery: lack of partners limits reproduction of the Black Stork (Ciconia nigra) at the margin of the distribution range. Ornis Fennica 96: 13-23. https://www.ornisfennica.org/pdf/ latest/19Konovalov.pdf

Kurlavicius P, Kuuba R, Lukins M, Mozgeris G, Tolvanen P, Angelstam P, Karjalainen H \& Walsh M. 2004. Identifying high conservation value forests in the Baltic States from forest databases. Ecological Bulletins 51: 351-366. https://www.jstor.org/ stable/20113321

Lindell L. 2002. Sveriges fåglar: aktuell översikt över deras utbredning, numerär och flyttning. Sveriges Ornitologiska Förening, Stockholm, Sweden.

Linder P \& Östlund L. 1998. Structural changes in three mid-boreal Swedish forest landscapes, 1885-1996. Biological conservation 85: 9-19. https://doi.org/10.1016/Sooo6-3207(97)00168-7

Lord CM, Wirebach KP, Tompkins J, Bradshaw-Wilson C \& Shaffer CL. 2020. Reintroduction of the European bison (Bison bonasus) in central-eastern Europe: a case study. International Journal of Geographical Information Science 34: 1628-1647. https://doi.org/10.1 $080 / 13658816.2019 .1672876$

Luthin CS. 1987. Status of and conservation priorities for the world's stork species. Colonial Waterbirds 10: 181-202. https://doi. org/10.2307/1521258 
Lõhmus A \& Sellis U. 2003. Nest trees-a limiting factor for the Black Stork (Ciconia nigra) population in Estonia. Aves 40: 84-91. https://www.aves.be/fileadmin/Aves/Bulletins/Articles/40_1-4/40_1-4_84.pdf

Lõhmus A, Sellis U \& Rosenvald R. 2005. Have recent changes in forest structure reduced the Estonian black stork Ciconia nigra population? Biodiversity and Conservation 14: 1421-1432. https:// doi.org/10.1007/s10531-004-9667-5

Lõhmus A. 2006. Nest-tree and nest-stand characteristics of forest-dwelling raptors in east-central Estonia: implications for forest management and conservation. Proceedings of the Estonian Academy of Sciences, Biology and Ecology 55: 31-50. http://vana.kirj. ee/public/va_\%2obo/bio-2006-1-3.pdf

Meggs JM, Munks SA, Corkrey R \& Richards K. 2004. Development and evaluation of predictive habitat models to assist the conservation planning of a threatened lucanid beetle, Hoplogonus simsoni, in north-east Tasmania. Biological Conservation 118: 501-511. https://doi.org/10.1016/j.biocon.2003.10.001

Meltofte H. 1987. What kind of bird fauna do we prefer? Acta Regiae Societatis Scientiarum Et Litterarum Gothoburgensis: Zoologica 14: $176-181$.

Næsset E. 2002. Predicting forest stand characteristics with airborne scanning laser using a practical two-stage procedure and field data Remote Sensing of Environment 80: 88-99. https://doi.org/10.1016/ Soo34-4257(01)00290-5

Nilsson M, Nordkvist K, Jonzén J, Lindgren N, Axensten P, Wallerman J, Egberth M, Larsson S, Nilsson L, Eriksson J \& Olsson H. 2017. A nationwide forest attribute map of Sweden predicted using airborne laser scanning data and field data from the National Forest Inventory. Remote Sensing of Environment 194: 447-454. https://doi.org/10.1016/j.rse.2016.10.022

Olsson O. 2007. Genetic Origin and Success of Reintroduced White Storks. Conservation Biology 21: 1196-1206. https://doi. org/10.1111/j.1523-1739.2007.00763.x

Olsson O \& Rogers DJ. 2009. Predicting the distribution of a suitable habitat for the white stork in Southern Sweden: identifying priority areas for reintroduction and habitat restoration. Animal Conservation 12: 62-7o. https://doi.org/10.1111/j.1469-1795.2008.00225.x

Oppel S \& Beaven B. 2002. Stewart Island robins (Petroica australis rakiura) fly home after transfer to Ulva Island. Notornis 49 : 180-181. https://www.notornis.osnz.org.nz/system/files/Notornis_49_3_180.pdf

Pande, S, Pawashe A, Deshpande P, Sant N, Kasambe R \& Mahabal A. 2006. Recent records, review of wintering distribution, habitat choice and associations of Black Stork Ciconia nigra in India and Sri Lanka. Biota 7: 65-75

Pedersen PBM, Ejrnæs R, Sandel B \& Svenning J-C. 2020. Trophic Rewilding Advancement in Anthropogenically Impacted Landscapes (TRAAIL): A framework to link conventional conservation management and rewilding. Ambio 49: 231-244. https://doi. org/10.1007/s13280-019-01192-z

Pihl S, Clausen P, Laursen K, Madsen J \& Bregnballe T. 2003. Danmarks Miljøundersøgelser: Bevaringsstatus for fuglearter omfattet af EF-Fuglebeskyttelsesdirektivet. Faglig rapport fra DMU, 462. Danmarks Miljøundersøgelser, Miljøministeriet, Copenhagen, Denmark. https://www2.dmu.dk/1_viden/2_Publikationer/3_ fagrapporter/rapporter/FR462.PDF

Poirazidis K, Papageorgiou AC \& Kasimiadis D. 20o6. Mapping the Animal Biodiversity in the Dadia National Park using MultiCriteria Evaluation Tools and GIS. Management and Development of Mountainous and Island Areas. Proceedings of the 2006 Naxos International Conference 2: 299-304. http://citeseerx.ist.psu. edu/viewdoc/download;jsessionid $=$ Co252DE09DC738E44B77BE404F1119FC?doi=10.1.1.708.903\&rep=rep1\&type $=$ pdf

Powell M, Accad A \& Shapcott A. 2005. Geographic information system (GIS) predictions of past, present habitat distribution and areas for re-introduction of the endangered subtropical rainforest shrub Triunia robusta (Proteaceae) from south-east Queensland Australia. Biological Conservation 123: 165-175. https://doi. org/10.1016/j.biocon.2004.11.004

Reading RP, Clark TW \& Kellert SR. 2002. Towards an endangered species reintroduction paradigm. Endangered Species Update 19: 142-146.

Rosenvald R \& Lõhmus A. 2003. Nesting of the black stork (Ciconia nigra) and white-tailed eagle (Haliaeetus albicilla) in relation to forest management. Forest Ecology and Management 185: 217-223. https://doi.org/10.1016/So378-1127(03)oo216-o

Sackl P. 1985. Der Schwarzstorch (Ciconia nigra) in Osterreich Arealausweitung, Bestandsentwicklung und Verbreitung. Die Vogelwelt 4: 121-141.

Sarrazin F \& Barbault R. 1996. Reintroduction: challenges and lessons for basic ecology. Trends in Ecology and Evolution 11: 474-478. https://doi.org/10.1016/0169-5347(96)20092-8

Seddon P, Armstrong D \& Maloney R. 2007. Developing the Science of Reintroduction Biology. Conservation Biology 21: 303-312. https://doi.org/10.1111/j.1523-1739.2006.00627.x

Smeraldo S, Bosso L, Fraissinet M, Bordignon L, Brunelli M, Ancillotto L \& Russo D. 2020. Modelling risks posed by wind turbines and power lines to soaring birds: the black stork (Ciconia nigra) in Italy as a case study. Biodiversity and Conservation 29: 1959-1976. https:// doi.org/10.1007/s10531-020-01961-3

Strazds M. 2003. Longevity of Black Stork (Ciconia nigra) nests and nest site protection in Latvia. Aves 40: 69-71.

Strazds M. 2011. Conservation ecology of the black stork in Latvia. PhD thesis, University of Latvia, Riga, Latvia.

SVAR. 2011. Faktablad nr 53. SMHI, Norrköping, Sweden. http:// www.smhi.se/polopoly_fs/1.17832!/webbFaktablad_53.pdf [2020-08-12]

Svensson S, Svensson M \& Tjernberg M. 1999. Svensk fågelatlas. Sveriges Ornitologiska Förening, Stockholm, Sweden.

Naturvårdsverket. 2020. Åtgärdsprogram för hotade arter och naturtyper. https://www.naturvardsverket.se/amnesomraden/ arter-och-artskydd/\#E563663292 [2022-01-05]

Tamás EA. 2011. Longevity and survival of the black stork Ciconia nigra based on ring recoveries. Biologia 66: 912-915. https://doi. org/10.2478/s11756-011-0090-6

Thatcher CA, Manen FTV \& Clark JD. 2oo6. Identifying suitable sites for Florida panther reintroduction. Journal of Wildlife Management 70: 752-763. https://doi.org/10.2193/oo22-541X(2006)70[752:IS SFFP] 2.0.CO;2

Treinys R, Lõhmus A, Stončius D, Skuja S, Drobelis E, Šablevičius B, Rumbutis S, Dementavičius D, Naruševičius V, Petraška A \& Augutis D. 2008. At the border of ecological change: status and nest sites of the Lithuanian Black Stork Ciconia nigra population 2000-2006 versus 1976-1992. Journal of Ornithology 149: 75-81. https://doi.org/10.1007/s10336-007-0220-7

Treinys R, Stončius D, Augutis D \& Skuja S. 2009. Breeding habitat of the Black Stork Ciconia nigra in Lithuania: Implications for conservation planning. Baltic Forestry 15: 33-40. https://www. balticforestry.mi.lt/bf/PDF_Articles/2009-15[1]/BFo9\%20 15(1)\%2op\%203340.pdf

Treinys R, Mozgeris G \& Skuja S. 2016. Can intensified forestry be responsible for changes in habitat usage by the forest-dwelling Black Stork? European Journal of Forest Research volume 135: 1175-1186. https://doi.org/10.1007/s10342-016-1003-6 
Tucker GM \& Heath MF. 1994. Birds in Europe: Their conservation status. BirdLife Conservation Series No. 3. BirdLife International, Cambridge, UK.

Ulfstrand S. 1973. Fåglar - Djurens värld: En populärvetenskaplig framställning av djurens liv. Nordens boktryckeri, Malmö.

Wintle BA, Elith J \& Potts JM. 2005. Fauna habitat modelling and mapping: A review and case study in the Lower Hunter Central Coast region of NSW. Austral Ecology 30: 719-738. https://doi. org/10.1111/j.1442-9993.2005.01514.X
Young R. 2003. Environmental Enrichment for Captive Animals. Iowa State Press, Ames, Iowa, USA. https://doi. org/10.1002/9780470751046

Zieliński P. 2006. The role of forest reserves in the protection of the Black Stork Ciconia nigra in central Poland. Biota 7: 119-123.

\section{Svensk sammanfattning}

Att återintroducera en tidigare förekommande art kan vara en relevant och lovvärd restaureringsåtgärd givet att orsaken till dess försvinnande har hanterats och justerats. En ökad förståelse för att rädda hotade och lokalt utrotade arter har lett till omfattande restaurering och bevarande av arter genom återintroduktioner. För att en återintroduktion ska lyckas är det dock nödvändigt med bakgrundsinformation om artens specifika habitatkrav. Svart stork Ciconia nigra betraktas som lokalt utdöd i Sverige. Upprepade, sentida observationer och till och med möjliga häckningar indikerar att förutsättningarna för svart stork som häckande art potentiellt har blivit gynnsamt igen. I denna studie använder vi oss av kunskap om arten och dess preferenser för att skapa modeller för att identifiera lämpliga habitat för återintroduktion av svart stork till Sverige. Dessa modeller påvisar flera områden i svarta storkens tidigare utbredningsområde i södra Sverige som lämpar sig för återintroduktion. Sju regioner innehöll mer än $18 \%$ lämpliga habitat i förhållandet till länets hela areal, med Jönköpings län (25.8 \%) i topp, följt av Blekinge län (23.9\%), Västra Götalands län (22.1\%) och Kronobergs län $(20.7 \%)$. Vi föreslår att dessa regioner bör vara primära målområden för en återintroduktion av svart stork till Sverige.

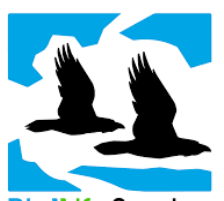

Birdlife Sverige

Ornis Svecica (ISSN 2003-2633) is an open access, peer-reviewed scientific journal published in English and Swedish by BirdLife Sweden. It covers all aspects of ornithology, and welcomes contributions from scientists as well as non-professional ornithologists. Accepted articles are published at no charge to the authors. Read papers or make a submission at os.birdlife.se.

Ornis Svecica (ISSN 2003-2633) är en fritt tillgänglig granskad vetenskaplig tidskrift som ges ut på svenska och engelska av BirdLife Sverige. Den täcker ornitologins alla områden och välkomnar bidrag från såväl forskare som icke-professionella ornitologer. Accepterade uppsatser publiceras utan kostnad för författarna. Läs uppsatser eller skicka in ditt bidrag på os.birdlife.se. 